\title{
Chemopreventive Efficacy of Ginger Extract (Zingiber officinale)
}

\author{
Harliansyah $^{1 *}$, W.N. Wan Zurinah ${ }^{2}$, M.Y.Yasmin Anum ${ }^{2}$, M. Noor Azian ${ }^{3}$ \\ ${ }^{1}$ Department of Biochemistry, Yarsi University School of Medicine, Jakarta, Indonesia \\ ${ }^{2}$ Department of Biochemistry, Faculty of Medicine, Universiti Kebangsaan Malaysia \\ ${ }^{3}$ Centre of Lipids and Engineering and Applied Research, Universiti Teknologi Malaysia
}

\begin{abstract}
The liver cells were cultured in the presence of ginger extract at various concentrations $(0-\mathrm{I} \mathrm{mg} / \mathrm{ml}$ ) for $24 \mathrm{~h}$ and the cells viability and proliferation rate were evaluated by MTS and BrdU assays, while apoptosis was evaluated by colorimetric determination of caspase 8 and 3 activities. Ginger extract exhibited a dose dependent inhibition of viability and proliferation of WRL-68, HLE and HepG2 cells with IC50 of $569.69 \pm$ $7.99 \mu \mathrm{g} / \mathrm{ml}, 389.7 \mathrm{I} \pm 26.56 \mu \mathrm{g} / \mathrm{ml}$ and $358.7 \mathrm{I} \pm 17.12 \mu \mathrm{g} / \mathrm{ml}$ respectively. Ginger extract induced apoptosis through activation of caspase- 8 and 3 in a dose dependent pattern for all cells at concentration ranging from $0-500 \mu \mathrm{g} / \mathrm{ml}$. We found that antiproliferative effect of ginger extract could be associated with induction of apoptosis as shown by increased activities of caspase 8 and 3.The results from this study suggest that ginger extract has chemopreventive properties against hepatoma cells HepG2 and HLE by inhibiting cellular proliferation and inducing apoptosis.
\end{abstract}

Keywords: antiproliferation, apoptosis, caspases, Zingiber officinale

\section{INTRODUCTION}

Hepatocellular carcinoma (hepatoma or $\mathrm{HCC}$ ) is one of the most common cancers in the world with an annual incidence of approximately 1 million deaths, mainly in underdeveloped and developing countries (Feo et al., 2006: Thorgeirsson and Grisham, 2002). The major risk factors for $\mathrm{HCC}$ are chronic infection with hepatitis B virus (HBV) or hepatitis C virus (HCV), cigarette smoking, heavy alcohol consumption and dietary exposures to the food contaminants such as aflatoxin (Wild and Hall, 2000).Recent studies have linked oxidative stress and chronic inflammation with an increased risk of cancer. It is hypothesized that oxidative stress and the generation of reactive oxygen species (ROS) or reactive nitrogen species (RNS) can cause mutations in cancer related genes or alter the function of important proteins regulating DNA repair, cell cycle and apoptosis (Wang et al., 2004). An imbalance between cytoproliferation and apoptosis may be relevant in liver carcinogenesis. Cell proliferation and apoptosis are highly regulated processes aimed at maintaining homeostasis in multi cellular organisms and which, when altered may be directly involved in the process of carcinogenesis in the liver (Farinati et al., 2001).

The use of herbal medicines in the treatment of cancer has increased over the last decade (Issa et al., 2006). Chemoprevention is the use of small molecules, including dietary or herbal chemicals to prevent diseases as opposed to chemotherapeutics where chemicals mostly synthetic are used to remove or alleviate the symptoms of disease (Gosslau and Chen, 2004).

\footnotetext{
*Corresponding author email : ianshr2001@yahoo.com,
} 
Ginger (Zingiber officinale Roscoe) is used worldwide as a cooking spice, condiment and herbal remedy.The major active ingredients in ginger with antioxidant properties are gingerol, shogaol, paradol, gingeol and zingerone (Tjendraputra et al., 2001; Chrubasik et al., 2005; Bhattacharjee, 2000). Ginger's extract has a variety of medicinal effects: analgesic, sedative, antipyretic, and antibacterial properties in in vitro and in vivo studies (Mascolo et al., 1989). Gingerol and paradol have inhibitory effects on the viability and DNA synthesis of human leukemia cells (Lee and Surh, 1998; Surh and Lee, 1998). In human erythrocyte membranes, ginger extracts inhibited lipid peroxidation (Sujatha and Srinivas, 1995).

One of the attractive strategies considered in current cancer prevention or therapy is to induce death of preneoplastic or malignant cells through apoptosis (Lee et al., 1998). There are accumulated evidence that certain phytochemicals present in medicinal herbs and dietary plants exert antitumorigenic activity by inducing apoptosis in cancer cells (Lee et al., 2004; Keum et al., 2002; Tong et al., 2004; Hsu et al., 2004; Bold et al., 1997). Caspase 3 and 8 activities are good indication of cells undergoing apoptosis since these enzymes are involved in the cells signaling pathways that lead to apoptosis (Hsu et al., 2004). The activation of caspase is known to play a pivotal role in the initiation and execution of apoptosis induced by various stimuli. When cells are undergoing apoptosis, executioner caspase-3 triggers cellular proteins and DNA fragmentation factor, resulting in the characteristic changes of apoptosis (Keum et al., 2002; Tong et al., 2004; Hsu et al., 2004; Bold et al., 1997). The objective of this study is to determine the anti-cancer effect of ginger extracts (Zingiber officinale) by examining cytotoxicity activity, proliferation and apoptotic properties of the extract on liver cancer cells, HepG2 and HLE.

\section{METHODS}

\section{Ginger extract}

Ginger extract was obtained by ethanol extraction as provided by Dr Noor Azian Murad from Center for Lipids Engineering Applied Research (CLEAR), Universiti Teknologi Malaysia.

\section{Cell line and culture}

HLE, HepG2 and WRL-68 cells were obtained from American Type Culture Collection (ATCC, Rockville, MD). HLE cells were maintained in Dulbecco's minimum essential medium (DMEM), while HepG2 and WRL-68 cells were maintained in Eagle's minimum essential medium (EMEM) supplemented with $10 \%$ heat inactivated foetal bovine serum (FBS) and $1 \%$ penicillin-streptomycin. The cells were cultured as a monolayer in plastic $75 \mathrm{~cm}^{2}$ tissue culture flask and grown at $37^{\circ} \mathrm{C}$ in humidified atmosphere of $5 \% \quad \mathrm{CO}_{2}$. Cell's viability, proliferation and apoptosis were performed when the cells reached $70-80 \%$ confluence. Ginger extract was added to cell line after 24 hours incubation.

\section{Cell viability}

HepG2 and WRL-68 cells at a density of $2 \times 10^{4}$ cells $/ \mathrm{ml}$ were plated in 96 well microtiter plates. After $24 \mathrm{~h}$ of incubation to allow for cell attachment, the cells were treated with $100 \mu \mathrm{l}$ of varying concentrations of ginger extract $(5,10,50$, $100,200,500$ and $1000 \mu \mathrm{g} / \mathrm{ml}$ ) in complex medium and incubated again for $24 \mathrm{~h}$ at $37^{\circ} \mathrm{C}$ under $5 \% \mathrm{CO}_{2}$. Three hours after the addition of MTS solution, the amount of formazan formed was measured spectrophotometrically at $490 \mathrm{~nm}$ with microplate reader Versamax-Molecular, Devices B-02865. Fifty percent inhibitory concentration $\left(\mathrm{IC}_{50}\right)$ of ginger extract in HLE, HepG2 and WRL-68 cells were calculated from triplicate wells.

\section{Cell Proliferation}

Cellular proliferation of HepG2 and WRL68 cells were measured using BrdU kit (Roche Diagnostics, Germany). HepG2 and WRL-68 cells were seeded into 96 well plates at a concentration of $2 \times 10^{4}$ cells $/ \mathrm{ml}$ in EMEM while HLE in DMEM with $10 \%$ FBS. Cells were incubated with various dilutions of ginger extract in a 96-well plates at a final volume of $100 \mu \mathrm{l} /$ well for $24 \mathrm{~h}$ in a humidified atmosphere at $37^{\circ} \mathrm{C} .10 \mu \mathrm{l}$ of $\mathrm{BrdU}$ labeling solution were added in cells and incubated for another $24 \mathrm{~h}$ at $37^{0} \mathrm{C}$. $100 \mu \mathrm{l} /$ well anti-BrdUPOD working solution was added and incubated for $90 \mathrm{~min}$ at $25^{0} \mathrm{C}$. After final rinsing, $100 \mu \mathrm{l} / \mathrm{well}$ substrate solution was added and incubated at $25^{\circ}$ $\mathrm{C}$ until color development was sufficient for photometric detection. Using ELISA reader (Versamax-Molecular, Devices.B-02865) at 450 $\mathrm{nm}$ (reference wavelength; $690 \mathrm{~nm}$ ).

\section{Activity of Caspase-8 and 3}

The assays were performed according to the manufacturer's instruction after a $24 \mathrm{~h}$ incubation with ginger extracts. Briefly, for each reaction 
$2 \times 10^{6}$ cells were lysed and incubated with the provided colorimetric substrates [N-acetyl-ile-gluthr-asp (Ac-IETD)-p-nitroaniline for caspase 8 and N-Acetyl-asp-glu-val-asp

(Ac-DEVD)-pnitroaniline for caspase 3] at $37^{\circ} \mathrm{C}$ for $2 \mathrm{~h}$. These substrates are cleaved by activated caspase $8 /$ caspase 3 to yield a colour product with an emission wavelength of $405 \mathrm{~nm}$. Results are expressed as the percent change of the activity compared to the untreated control.

\section{Statistical Analysis}

Statistically significant differences were assessed using the Student's t test.

\section{RESULTS AND DISCUSSION}

Ginger extract of Zingiber officinale reduced viability of all cells (WRL-68, HLE and HepG2) significantly $(\mathrm{p}<0.01)$, after $24 \mathrm{~h}$ treatment at concentrations ranging from $0-1 \mathrm{mg} / \mathrm{ml}$ (figure 1). A decrease in cells viability can be interpreted as the cytotoxic effects of ginger extract on cancer cells. The extract is not toxic to normal cell line (WRL-68) since it needed a higher amount of the extract to inhibit $50 \%$ of its viability $\left(\mathrm{IC}_{50}\right), 569.69 \pm 7.99 \mu \mathrm{g} / \mathrm{ml}$, as compared to $389.71 \pm 26.56 \mu \mathrm{g} / \mathrm{ml}$ for HLE and $358.71 \pm 17.12$ $\mu \mathrm{g} / \mathrm{ml}$ for HepG2. Normal cells did not show any sign of necrotic cells due to the effect of ginger extract as seen in the microscope.

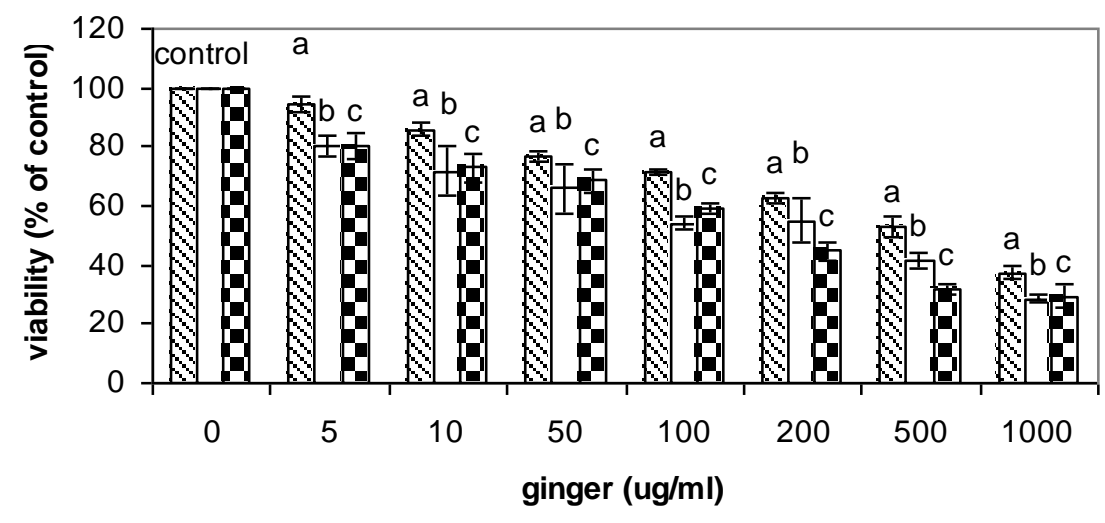

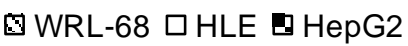

Figure.I. Effect of ginger extract on viability of WRL-68, HLE and HepG2 cells. Data are reported as mean \pm SD $(n=3)$. a, significant difference $(p<0.0 I)$ when compared to no addition for WRL-68 cells. $b$, significant difference $(p<0.01)$ when compared to no addition for HLE cells. $c$, significant difference $(p<0.01)$ when compared to no addition for HepG2 cells.

Ginger extract of Zingiber officinale inhibited proliferation of hepatoma cells HLE and HepG2 significantly $(\mathrm{p}<0.01)$, after $24 \mathrm{~h}$ treatment in a dose dependent manner (figure 2). Ginger extract at 200, 500 and $1000 \mu \mathrm{g} / \mathrm{ml}$ inhibited proliferation of HLE cells by $62 \%, 47 \%$ and $40 \%$ respectively and HepG2 cells proliferation by $67 \%, 59 \%$ and $42 \%$ respectively. This shows the high anti-cancer activity of ginger extract since as low as $200 \mu \mathrm{g} / \mathrm{ml}$ was able to inhibit more that $50 \%$ of both hepatoma cells. 


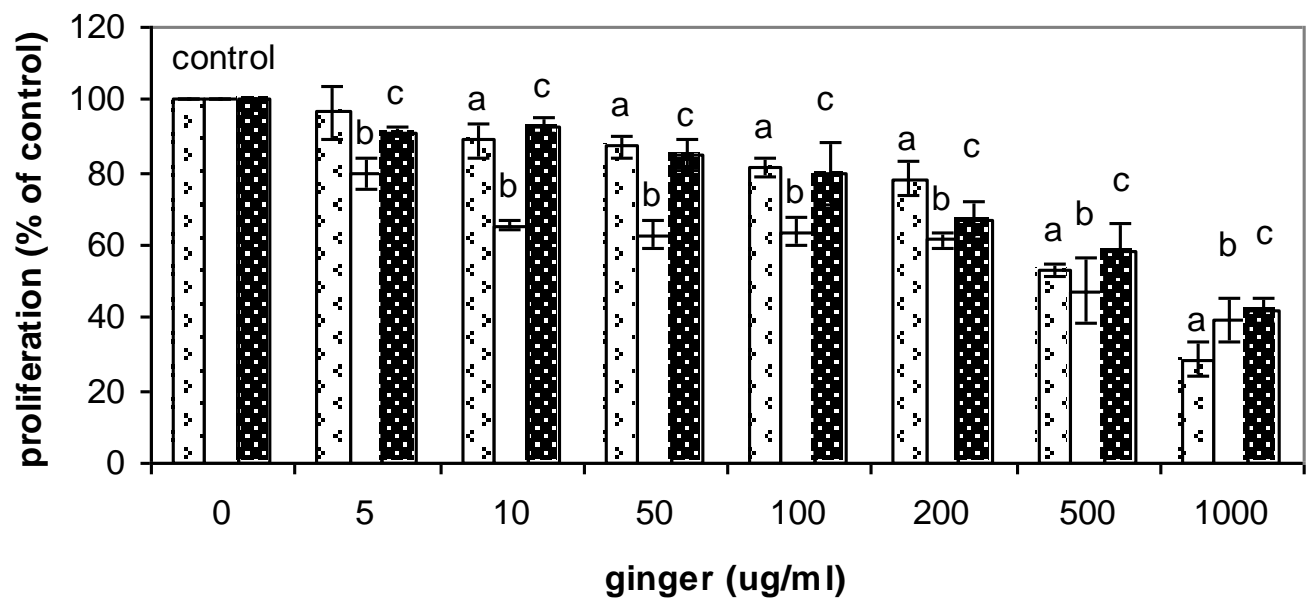

๑ WRL-68 口 HLE $\mathbf{Q}$ HepG2

Figure.2. Effect of ginger extract on proliferation of WRL-68, HLE and HepG2 cells. Data are reported as mean $\pm S D(n=3)$. a, significant difference $(p<0.01)$ when compared to no addition for WRL-68 cells. $b$, significant difference $(p<0.0 I)$ when compared to no addition for HLE cells. $c$, significant difference $(p<0.01)$ when compared to no addition for HepG2 cells.

Apoptosis as measured by caspase- 8 and 3 activities was maximal at ginger extract concentration ranging between $250-500 \mu \mathrm{g} / \mathrm{ml}$ (corresponding to $\mathrm{IC}_{50}$ values) for all cell lines tested with HLE cells exhibiting the highest caspase- 8 and 3 activities at $500 \mu \mathrm{g} / \mathrm{ml} /$ (figure 3 and figure 4). Caspase-8 activation which is involved in apoptosis process, can initiate two pathways leading to the activation of downstream caspases such as caspase- $3,-6$ and -7 by direct cleavage (Budihardjo et al., 1999).

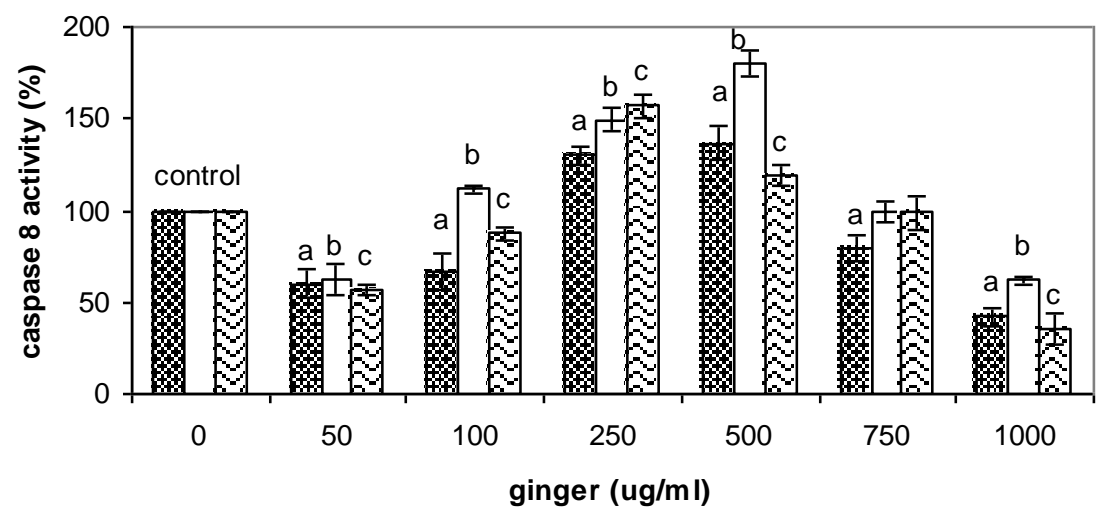

WRL-68 $\square$ HLE $\bullet$ HepG2

Figure.3. Effect of ginger extract on the caspase 8 activity of WRL-68, HLE and HepG2 cells. Data were presented as mean \pm SD $(n=3)$. a, significant difference $(p<0.01)$ when compared to no addition for WRL-68 cells. b. significant difference $(p<0.0 I)$ when compared to no addition for HLE cells. $c$, significant difference $(p<0.0 \mathrm{I})$ when compared to no addition for HepG2 cells. 


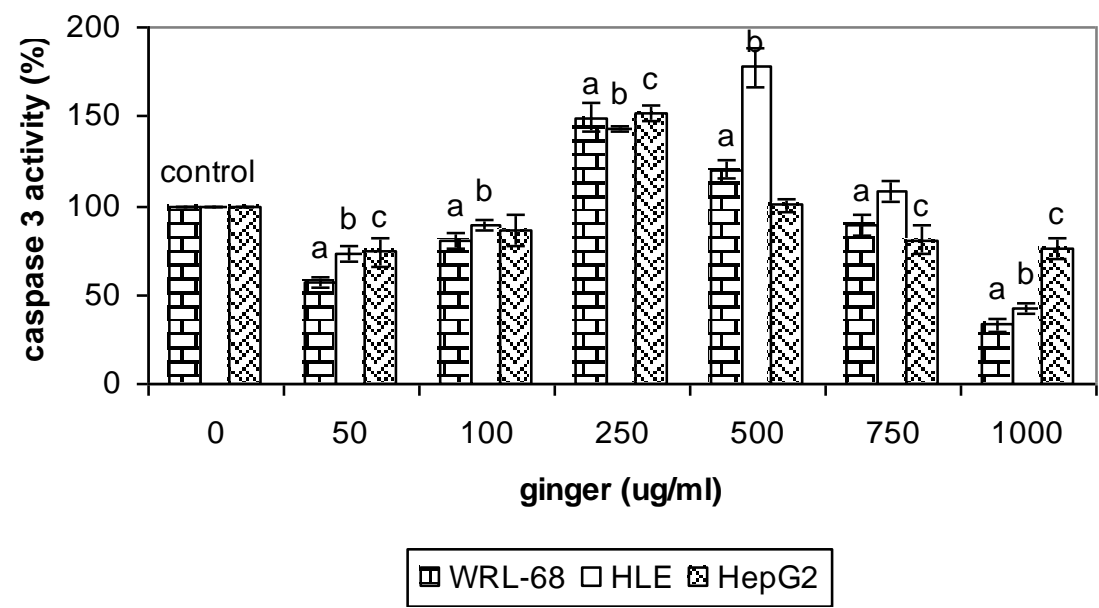

Figure.4. Effect of ginger extract on the caspase 3 activity of WRL-68, HLE and HepG2 cells. Data were presented as mean \pm SD $(n=3)$. a, significant difference $(p<0.0 I)$ when compared to no addition for WRL-68 cells. b. significant difference $(p<0.01)$ when compared to no addition for HLE cells. $c$, significant difference $(p<0.01)$ when compared to no addition for HepG2 cells.

\section{CONCLUSION}

Our results suggest that ethanolic extracts of Zingiber officinale exhibited anti-cancer effects by inhibiting proliferation of hepatoma cells (HepG2 and HLE) and inducing apoptosis via activation of caspase 8 and caspase 3 activities.

\section{ACKNOWLEDGMENTS}

This work was supported by MOSTI (Malaysian Science \& Technology Innovation) grant.

\section{REFERENCES}

Feo, F., De Miglio, M. R., Simile, M. M., Muroni, M.R., Calvisi, D.F., Frau, M. and Pascale, R.M., 2006, Hepatocellular carcinoma as a complex polygenic disease. Interpretative analysis of recent development on genetic predisposition, Biochim. Biophys. Acta, 1765, 126-147.

Thorgeirsson, S.S. and Grisham, J.W., 2002, Molecular pathogenesis of human hepatocellular carcinoma, Nature Gen., $\mathbf{3}$ I, 339- 346.

Wild, C.P. and Hall, A.J., 2000, Primary prevention of hepatocellular carcinoma in developing countries, Mutation Res., 462, 38I-393.

Wang, X.W., Hussain, S.P., Huo, T.I., Wu, C.G., Forgues, M., Hofseth, L.J., Brechot, C. and Harris, C.C., 2002, Molecular pathogenesis of human hepatocellular carcinoma, Toxicology, I8 I- I 82, 43-47.

Farinati, F., Cardin, R., Fiorentino, M., D’Errico, A., Grigioni, W. and Cecchetto, A., 200I, Imbalance between cytoproliferation and apoptosis in hepatitis $\mathrm{C}$ virus related chronic liver disease, J. Viral Hepatitis, 8, 34-40.

Issa, A.Y., Volate, S.R. and Wargovich, M.J., 2006, The role of phytochemicals in inhibition of cancer and inflammation: New directions and perspectives, J. Food Comp. Anal., 19, 405-4I9.

Gosslau, A. and Chen, K.Y., 2004, Nutraceuticals, apoptosis and disease prevention, Nutrition, 20, 95-102.

Tjendraputra, E., Tran, V.H., Brennan, D.L., Roufogalis, B.D. and Duke, C.C., 200I, Effect of ginger constituents and synthetic analogues on cyclooxygenase-2 enzyme in intact cells, Bioorganic Chem., 29, I56-163.

Chrubasik, S., Pittler, M.H. and Roufogalis, B.D., 2005, Zingiberis rhizome: a comprehensive review on the ginger effect and efficacy profiles, Phytomedicine, I2, 684-70I.

Bhattacharjee, S.K., 2000, Ginger (Zingiber officinale). In Handbook of aromatic plants, 473-474. India: Pointer Publishers.

Mascolo, N., Jain, R., Jain, S.C. and Capasso, F., 1989, Ethnopharmacologic investigation of ginger (Zingiber officinale), J. Ethnopharmacol, 27(I-2), 129-I40. 
Lee, E. and Surh, Y-J., 1998, Induction of apoptosis in HL-60 cells by pungent vanilloids [6]gingerol and [6]-paradol, Cancer Lett., 134, 163-168.

Surh, Y-J., Lee, E. and Lee, J-M., 1998, Chemoprotective properties of some pungent ingredients present in red pepper and ginger, Mutation Res., 402, 259-267.

Sujatha, R. and Srinivas, L., 1995, Modulation of lipid peroxidation by dietary components, Toxicol. In Vitro, 9(3), 23 I-236.

Lee, E., Park, K-K., Lee, J-M., Chun, K-S., Kang, JY., Lee, S-S. and Surh, Y-J., 1998, Suppression of mouse skin tumor promotion and induction of apoptosis in HL-60 cells by Alpinia oxyphylla Miquel (Zingiberaceae), Carcinogenesis, 19(8), 1377-1381.

Lee, J-Y., Hwang, W-I. and Lim, S-T., 2004, Antioxidant and anticancer activities of organic extracts from Platycodon grandiflorum A. De Candolle roots, J. Ethnopharmacol, 93, 409-4I5.
Keum, Y-S., Kim, J., Lee, K.H., Park, K.K., Surh, YJ., Lee, J.M., Lee, S-S., Yoon, J.H., Joo, S.Y., Cha, I.H. and Yook, J.I., 2002, Induction of apoptosis and caspase- 3 activation by chemopreventive [6]-paradol and structurally related compounds in KB cells, Cancer Lett., I77, 4I-47.

Tong, X., Lin, S., Fujii, M. and Hou, D-X., 2004, Molecular mechanisms of echinocystic acid-induced apoptosis in HepG2 cells, Biochem. Biophys. Res. Comm., 32I, 539546.

Hsu, Y-L., Kuo, P-L. and Lin, C-C., 2004, Acacetin inhibits the proliferation of HepG2 by blocking cell cycle progression and inducing apoptosis, Biochem. Pharmacol, 67, 823-829.

Bold, R.J., Termuhlen, P.M. and McConkey, D.J. 1997, Apoptosis, cancer and cancer theraphy, Surgical Oncol., 6, I33-142.

Budihardjo, I., Oliver, H., Lutter, M., Luo, X. and Wang, X., 1999, Biochemical pathways of caspase activation during apoptosis, Annu. Rev. Cell Dev. Biol. I5, 269-290. 